\title{
Neries hidroenergija
}

Jonas Jablonskis ${ }^{1}$,

Diana Meilutytè-Lukauskiené $\dot{e}^{1,2}$

${ }^{1}$ Lietuvos energetikos institutas,

Hidrologijos laboratorija,

Breslaujos g. 3, LT-44403 Kaunas

${ }^{2}$ Lietuvos sveikatos mokslu universitetas, A. Mickevičiaus g. 9, LT-44307 Kaunas

El.paštas diana.meilutyte-lukauskiene@lei.lt
Straipsnyje Neries pavyzdžiu tiriama upių tekkmẻ kaip mechaninès hidroenergijos šaltinis, kurị sudaro potencinè ir kinetinè hidroenergija. Šių hidroenergijų kiekis ir santykis - svarbūs ịsisavinant vietinius atsinaujinančius energijos išteklius. Duomenų baze sudaryta iš 1:25000 mastelio topografiniuose žemèlapiuose pateiktų hidrografinių charakteristikų, kurios atspindi upès nuosèkio laikotarpi. Sudarytos upès tèkmès greičio, pločio, gylio, skerspjūvio ploto ir nuolydžio duomenų eilès, atlikta jų kaitos pagal tèkmę analizè. Neries tèkmès skerspjūviams iš kinetinès ir potencinès energiju atskirai apskaičiuotos galios $P_{k}$ ir $P_{p}$ bei jų santykis - Frudo skaičius $\dot{F}$ r. Tyrimas parode, kad upés nuosèkio metu esant tèkmès greičiui $v=0,5-0,6 \mathrm{~m} / \mathrm{s}$, kinetinè galia siekia $0,34-2,3 \%$ potencinès galios. Manome, kad būtina išsamiau ištirti šalies upių srovès greičius ir gylius, jų hidroenergetinius išteklius.

Raktažodžiai: upè, energijos kinetinė galia, skerspjūvio plotas, vandens greitis, nuolydis, Frudo skaičius

\section{IVADAS}

Lietuva neturi pakankamai pirminès energijos išteklių, todèl apsirūpinti ja nèra paprasta. Europos Sąjunga visoms narèms pasiūlè užtikrinti, kad iki 2020 m. $20 \%$ energijos būtų gaminama iš atsinaujinančių energijos išteklių, ir $20 \%$ padidinti energijos vartojimo efektyvumą. Manoma, kad šioms užduotims igyvendinti, daugiau elektros energijos šalyje reiketų pasigaminti patiems, stengtis plačiau panaudoti vejjo ir saulès energiją, žemès ir vandens šilumą, biokurą bei atliekas šilumai ir elektros energijai gaminti, naudoti taupesnị apšvietimą, renovuoti namus, juose įrengiant saulès ir žemès šilumos kolektorius ir kt.

Per pastaruosius 25 metus energetikos sektoriuje įvyko reikšmingų pokyčių. Vienas jų - atsisakyta plètoti hidroenergetiką, kuri yra vienas svarbiausių atsinaujinančių energijos išteklių. Ma- noma, kad mažosios hidroenergetikos plètojimas neatitinka šalies darnios plètros strategijos. Seimas pakeitė Vandens ịstatymą, kuriuo uždraudè statyti užtvankas Nemune bei ekologiniu ir kultūriniu požiūriu svarbiose upèse ar jų ruožuose, o Vyriausybe $2004 \mathrm{~m}$. patvirtino šių upių sąrašą [1]. Todèl liko vos 2,6 \% visų teorinių hidroenergetinių išteklių, kurių šalyje yra apie $6,0 \cdot 10^{9} \mathrm{kWh}$ [2]. Ignalinos atominè elektrinè $2009 \mathrm{~m}$. pagamino 10 852,6 GWh elektros energijos (2009 m. pabaigoje buvo uždaryta), vejo elektrinès - 157,7 GWh, o mažosios hidroelektrinès $-74,3 \mathrm{GWh}$; toks gamybos lygis stebimas jau nuo $2007 \mathrm{~m}$. [3].

Dabartinei hidroenergetikos plètrai susidarè nepalankios perspektyvos [4]. Nežiūrint to, i̇vertinę susidariusią situaciją ir hidroenergetikos plètros pasaulinę praktiką plačiau panaudoti upių tèkmès ir jūros bangų kinetinès energijos technologijas, Aleksandro Stulginskio universiteto ir Lietuvos energetikos instituto hidroenergetikai 
siekia ištirti galimybes kinetinę hidroenergiją panaudoti šalyje, neịrengiant užtvankų. Paskelbti pirmieji tyrimų rezultatai [5-8].

Vandens tèkmès kinetinè energija ir jos praktinis panaudojimas nèra taip plačiai ištirtas, kaip potencinès energijos, nes ši energija, dar vadinama "gyvąja energija“, žymiai mažesnè. Tačiau ją galima naudoti netvenkiant upés, o turbinas panardinti upès tèkmèje ar patalpinti jos paviršiuje. Dèl ekologinių sumetimų kinetinés energijos tyrimai intensyveja ir yra atliekami dviem kryptimis: upių ir jūrų pakrančių vandens kinetinès energijos išteklių tyrimas ir jos išteklių nustatymas bei naujų technologijų kūrimas [5]. Upių kinetinès hidroenergijos ištekliai plačiai tiriami Kanadoje ir JAV [9-11].

Svarbiausi parametrai vandens tèkmes kinetinei energijai ịvertinti yra vandens masè ir jos judesys. Tačiau konkrečioms upèms juos nustatyti nèra paprasta, nes upé - per ilgą laiką gamtos jègų suformuotas kūrinys, tekantis per nevienalytį žemès paviršių. Todèl upès yra kintančio pločio, gylio, nuolydžio ir kitų morfometrinių rodiklių dinaminis vandens telkinys. Upių vagų ir tèkmès parametrai kinta, todèl nustatant upès kinetinę ir visą pilnutinę energiją reikia kuo išsamiau upę ištirti, išmatuojant arba modeliuojant upès skerspjūvio parametrus, ypač atkreipiant dèmeș $i \mathfrak{i}$ tèkmès greitị. Šiam tyrimui buvo panaudotos upių morfometrinès charakteristikos, nustatytos pagal palyginti stambaus mastelio topografinius žemèlapius.

Šio straipsnio tikslas - ne tik upès kinetinès energijos, bet ir upès tèkmès mechaninès energijos, kurią sudaro kinetinè ir potenciné (padèties ir slegio) energijos, ịvertinimas. Toks kompleksinis upès tyrimas jos energijos sudedamujų požiūriu igalina objektyviau ịvertinti upés hidroenergetinę vertę. Analizei pasirinkta antroji pagal dydị šalies upè Neris.

\section{METODIKA IR PRADINIAI DUOMENYS}

Pagal žinomą hidraulikoje Bernulio lygti, upès vandens tèkmès pilnutinę hidromechaninę energiją sudaro potencinès ir kinetinès energijų vienoda suma. Potencinę upés energiją nusako galimas jos tèkmès padèties aukščio pokytis, o kinetinę - upès tèkmès judejjimas:

$$
E_{p}=m \cdot g \cdot h,
$$

$$
E_{k}=0,5 \cdot m \cdot v^{2} .
$$

Norint ištirti upès hidroenergetinius išteklius, reikia šias energijos rūšis išnagrinèti atskirai ir išsiaiškinti jų santykị. Potencinè energija gali būti konvertuojama ị kinetinę ir atvirkščiai sąryšiu:

$$
m \cdot g \cdot h=0,5 \cdot m \cdot v^{2}
$$

nes tarp srovès greičio ir jo slègio aukščio $h$ egzistuoja santykis $v=\sqrt{2 g h}$. Srauto tūrio masę $m$ pakeitę srauto mase $\hat{\mathrm{m}}=\rho \mathrm{Av}(\mathrm{kg} / \mathrm{s})(A-$ skerspjūvio plotas, $\mathrm{m}^{2}$ ), rasime srauto energetinę galią (atliekamo darbo spartą):

$$
\begin{aligned}
& P_{p}=\hat{\mathrm{m}} \cdot g \cdot h, \\
& P_{k}=0,5 \cdot \hat{\mathrm{m}} \cdot v^{2} .
\end{aligned}
$$

Pilnutinę teorinę tèkmès hidromechaninę arba bendros hidraulinès energijos galią galima nustatyti vietoj slėgio aukščio prièmus bendrąji hidrodinaminị $h_{d}=h+h_{s}$ aukštị $\left(h_{s}=v^{2} / 2 g\right)$ :

$$
P_{m}=\hat{m} \cdot g \cdot h_{d}
$$

Kinetinès energijos vertę potencinès energijos požiūriu apibūdina jų galių santykis $\dot{F r}$ (Frudo skaičius), kuris dvigubai mažesnis už Fr skaičių, nustatytą pagal inercijos ir svorio jègų santykị. İvertinus (3) nuostatą:

$$
\dot{F} r=\frac{0,5 \hat{m} v^{2}}{\hat{m} g h}=\frac{0,5 \hat{m} 2 g h_{s}}{\hat{m} g h}=\frac{h_{s}}{h} .
$$

Tad kinetinès galios vertę galima nustatyti pagal hidrostatinio slègio $h_{s}$ ir slègio aukščio $h$ santyki. Frudo skaičiumi galima pasikliauti parenkant tinkamas vietas hidrokinetinems turbinoms išdèstyti upès tèkmèje, kai svarbu žinoti srovès greiti, upés gyli ir plotị bei kitus upès vagos parametrus.

Tiriant upès kinetinę energiją reikšmingą ir reikalingą informaciją teikia kinetinès energijos tankio rodikliai. Tai tèkmès galia $\left(P_{k}=500 v^{3}\right)$, tenkanti $1 \mathrm{~m}^{2}$ skerspjūvio plotui arba $1 \mathrm{~m}^{3} / \mathrm{s}$ vandens debitui $\left(P_{k}=500 v^{2}\right)$ (1 pav.), kuris rodo, kaip sparčiai (kubu ar kvadratu) auga srovès energija didejant jos greičiui.

Dèl riboto vandens matavimo stočių (VMS) tinklo trūksta duomenų, pateiktų formulių parametrams nustatyti. Iki 1969 m. hidrologiniuose 


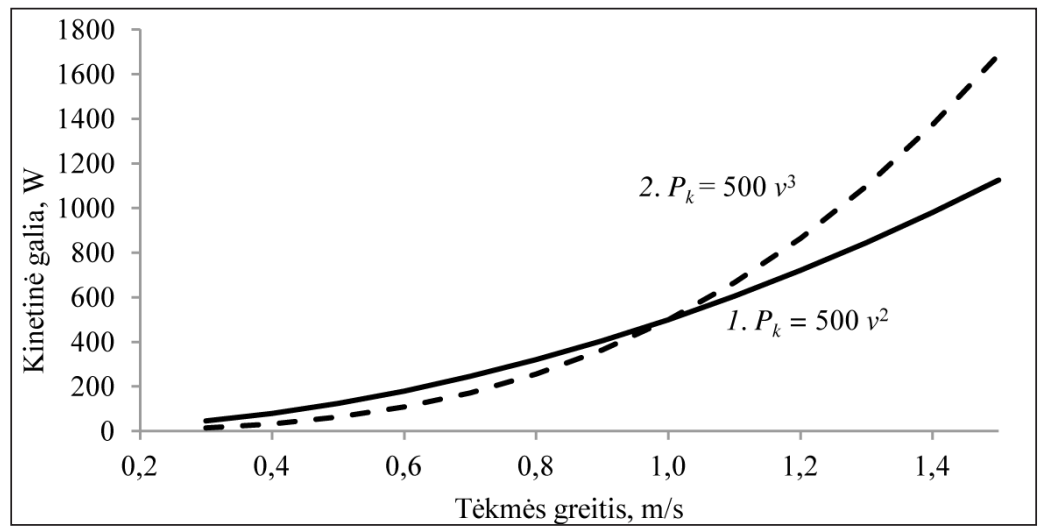

1 pav. Kinetinės energijos galios $P_{k}(\mathrm{~W})$ priklausomumas nuo srovès greičio $v(\mathrm{~m} / \mathrm{s})$, kai vandens debitas (Q) $1 \mathrm{~m}^{3} / \mathrm{s}(1)$ ir tèkmès skerspjūvio plotas $(A) 1 \mathrm{~m}^{2}(2)$

metraščiuose buvo skelbiami ne tik vandens debitai, bet ir jiems apskaičiuoti reikalingi duomenys (upés plotis ir gylis, skerspjūvio plotas, vandens greitis ir kt.). Dabartiniu metu skelbiami tik išmatuoti kiekvienos dienos vandens lygiai ir apskaičiuoti vandens debitai.

Tyrimui reikiamus duomenis galima rasti ir upių vandens parametrų epizodinių matavimų santraukose [12]. Pavyzdžiui, informacija apie Neri pateikta pagal hidrografinius vagos matavimus, atliktus $1957 \mathrm{~m}$. birželio 20 - rugpjūčio $25 \mathrm{~d}$. Tačiau šie duomenys pateikiami grafiškai, todèl skaičiavimams mažai tinkami; juos galima rasti tik archyvuose.

Šiame tyrime, skaičiuojant Neries kinetinę ir potencinę energiją, buvo naudojami upès morfometriniai duomenys, nustatyti iš 1:25000 mastelio topografinių žemèlapių. Šie žemèlapiai buvo naudojami nustatant šalies upių ilgius ir baseinų plotus [13] bei potencinès hidroenergijos išteklius [14]. Žemèlapiuose ìvairiu atstumu (vidutiniškai kas $3,5 \mathrm{~km}$ ) yra pateikiamas upés plotis ir gylis, vandens tèkmès greitis, vandens paviršiaus absoliutus aukštis ir kt.

Palyginus Buivydžių, Vilniaus ir Jonavos VMS „0“ aukččius su žemèlapiuose pateiktais vandens lygiais, pastarieji atitinkamai 1,96, 2,40 ir 0,26 metro yra aukštesni. Žemèlapiuose duomenys atitinka vidutinio vandeningumo metų $(1960,1964,1969)$ vasaros mènesių vandens lygius ir debitus.

\section{TYRIMŲ REZULTATAI IR APTARIMAS}

Upè siekia suformuoti pusiausvyros (igaubtos kreivès pavidalo) išilgini profili. Neris tokio profilio dar nesuformavo. Pagal žemėlapius nustatyta, kad, išskyrus trumpas atkarpas, Neries nuolydis beveik vienodas: vidutinis $-37,6 \mathrm{~cm} /$ $\mathrm{km}$, didžiausias $-45,0 \mathrm{~cm} / \mathrm{km}$ (tarp Vokès ir Musès upių žiočių). Upès tèkmès plotis $B$ pasroviui didejja monotoniškai-cikliškai, nes paeiliui sietuvas keičia rèvos, upe teka tartum per mažus ežerèlius. Plotis nuo Žeimenos iki Šventosios padidejja tik 30 metrų (nuo 60 iki 90), tačiau žemupyje jis jau siekia 200 metrų ir daugiau (2 pav.). Žemèlapiuose pateikiamos giliausios upés vietos. Profiliuose upés gylis kinta nuo 0,9 iki 3 metrų, vidutinis upés gylis $D=1,85 \mathrm{~m}$. Galima pažymèti, kad kai upès plotis $(B)$ yra per $180 \mathrm{~m}$, upès gylis - ne didesnis kaip vienas metras. Žemupyje upeje klostosi sąnašos, atsiranda salų, todèl $25 \mathrm{~km}$ žemupio ruože upè yra seklesnè.

Svarbus upès rodiklis yra jos skerspjūvio plotas $(A)$. Neries tèkmès skerspjūvio plotą apskaičiavome upés plotį $(B)$ padauginę iš 0,67 nuo maksimalaus gylio $\left(D_{\max }\right): A=0,67 \cdot D_{\max } \cdot \mathrm{B}$ (vidutiniškai toks $D_{\text {vid }}$ ir $D_{\max }$ gylių santykis stebimas parabolinio skersinio profilio upese). Neries skerspjūvio plotas pagal upés tèkmę turi ryškų didejantị trendą (2 pav.).

Žemèlapyje pateikti srovès greičiai nèra išsamūs. Sprendžiant pagal upès nuolydžius, srovès greičiai galètų būti pateikti tankiau. Neries aukštupyje srovès greitis $v=0,3-0,4 \mathrm{~m} / \mathrm{s}$, iki Želvos upès žiočių srovè padideja iki $0,5-0,7 \mathrm{~m} / \mathrm{s}$. Rèvuotoje upès dalyje, nuo Vokès iki Šventosios žiočių, vyrauja gana pastovus $0,6 \mathrm{~m} / \mathrm{s}$ srovès greitis, žemiau Šventosios žiočių greitis sumažèja iki $0,5 \mathrm{~m} / \mathrm{s}$. Tai vasaros nuosékio laikotarpio upès 


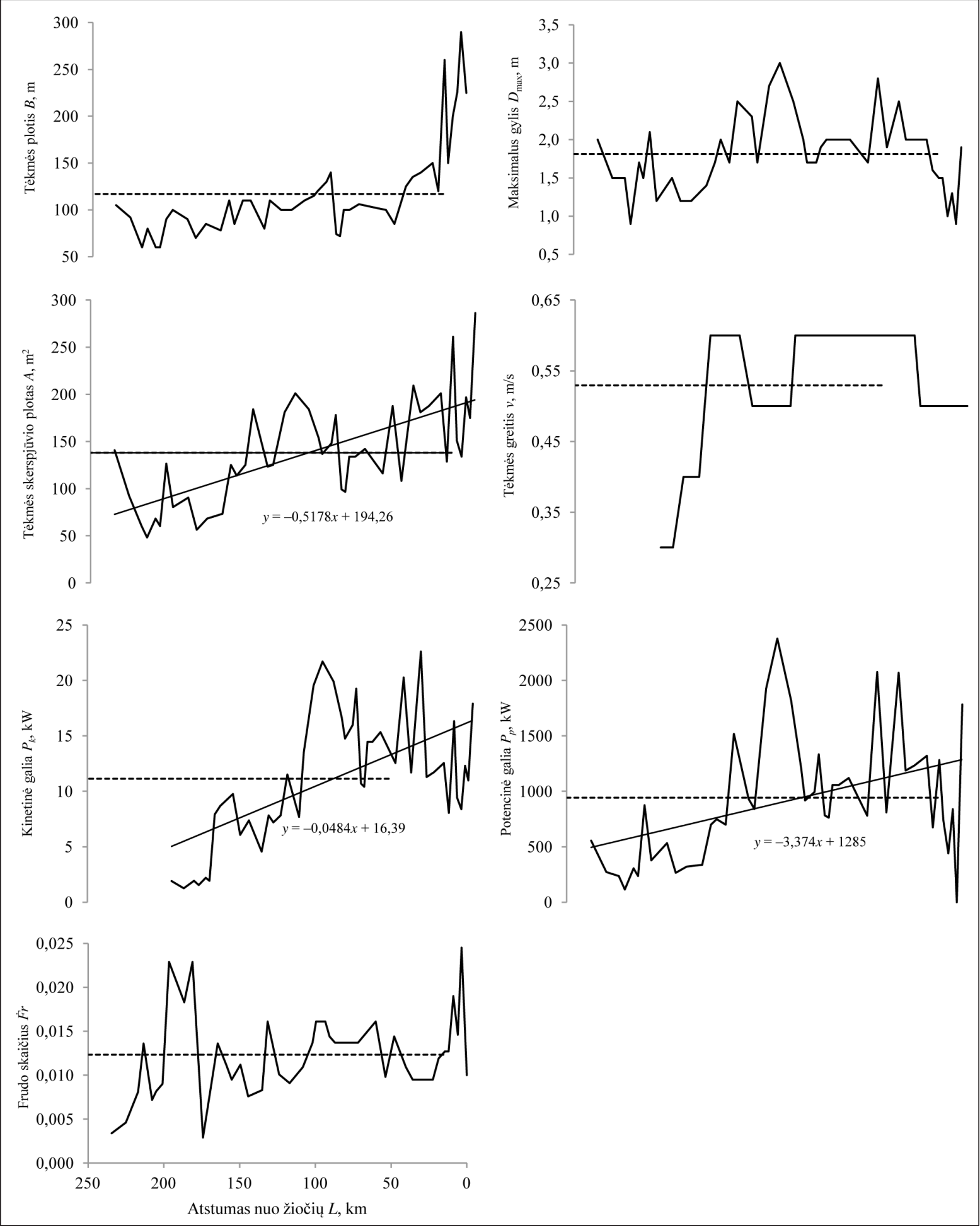

2 pav. Neries tèkmės charakteristikos ir hidroenergija upės skerspjūviuose (punktyrais atidètos vidutinės reikšmės)

srovès greičiai. Kiek didesni srovės greičiai buvo išmatuoti $1957 \mathrm{~m}$. birželị-rugpjūtị: Vilniaus VMS - 0,53-0,63 m/s, Jonavos VMS - 0,59$0,62 \mathrm{~m} / \mathrm{s}$. Tai $52-59 \%$ vandeningumo metų vandens greičiai.

\section{HIDROENERGIJOS GALIA UPĖS SKERSPJŪVIUOSE}

Neries vandens potencine $P_{p}$ ir kinetiné $P_{k}$ energijos galia upes skerspjūviuose apskaičiuotos pagal 
(4) ir (5) formules. Atlikus Neries skerspjūvių plotų $(A)$ ir pagal topografinius žemèlapius nustatytų vandens greičiu $(v)$ kaitos analizę (2 pav.), apskaičiuota, kad 44 upès skerspjūviuose kinetinè galia kinta nuo palyginti mažos $1,25-1,54 \mathrm{~kW}$ upès aukštupyje iki $20 \mathrm{~kW}$ vidurupyje ir sumažeja iki $15 \mathrm{~kW}$ upès žemupyje. Mažas $P_{k}$ reikšmes Neries aukštupyje lèmé maži srovés greičiai $(0,3-0,4 \mathrm{~m} / \mathrm{s})$; vidurupyje didesnėms $P_{k}$ reikšmèms ittakos turejo didesni srovès greičiai (iki $0,6 \mathrm{~m} / \mathrm{s}$ ) bei dèl pagilèjusios upès padidèjęs upès skerspjūvio plotas; žemupyje dèl iki $0,5 \mathrm{~m} / \mathrm{s}$ sumažejusio srovès greičio sumažèjo ir $P_{k}$ reikšmès, tačiau bendrą $P_{k}$ pokyti pagal tèkmę nulèmé upès vandeningumo augimas. Gautus duomenis galima apibendrinti tokia tiesine išraiška: $P_{k}=16,39-0,048 \mathrm{~L}$. Šia lygtimi galima nustatyti $P_{k}$ norimu upés atstumu $L$ nuo žiočių, tačiau praktiniu požiūriu svarbios tik didžiausios $P_{k}$ reikšmès. Iš 44 skerspjūvių tik trijuose nustateme $P_{k}>20 \mathrm{~kW}(40,3,53,8$ ir $117,0 \mathrm{~km}$ atstumu nuo upès žiočių). Juose srovès greitis $0,6 \mathrm{~m} / \mathrm{s}$, skerspjūvio plotai apie $200 \mathrm{~m}^{2}$.

Tiems patiems 44 Neries upès skerspjūviams buvo apskaičiuota ir potencinès energijos galia $\left(P_{p}\right)$, kurios kaitos pasroviui grafikas pateiktas 2 pav. Šio grafiko forma artima upès maksimalaus gylio $(D)$ grafiko formai.

Žinant energijų galias $P_{k}$ ir $P_{p}$, galima nustatyti bendrą upès tèkmès energijos galią $\left(P_{m}\right)$ ir šiu galių santyki $\left(P_{k} / P_{p}\right)$. Neries hidroenergijos galių balansas 44 skerspjüviuose: $P_{m}=P_{k}+P_{p}=941 \mathrm{~kW}$. Galima daryti išvadą, kad Neries hidromechaninès energijos galia, nustatyta pagal 44 upès skerspjūvių galių vidurki, yra $941 \mathrm{~kW}$, kurios didžiausią $(930 \mathrm{~kW}$ ) dali sudaro potencinè ir tik $11 \mathrm{~kW}$ - kinetinè galia. Beje, kinetinè energija gali būti nustatyta ne pagal hidromechaninę, bet pagal apskaičiuotą potencinès energijos galią, tačiau būtina ištirti $P_{k}$ ir $P_{p}$ santyki, t. y. kinetiškumo parametrą - Frudo skaičių, kuris apskaičiuojamas pagal (7) formulę (2 pav.).

Tirtuose 44 Neries skerspjūviuose Frudo skaičius $(\dot{F r})$ kinta nuo 0,0034 iki 0,0229, vidutinè reikšmè 0,0127 . Tai rodo, kad šiuo atveju kinetinè galia siekia $0,3-2,3 \%$, o vidutiniškai - $1,27 \%$ potencinès galios.

Kadangi apie $99 \%$ tèkmès mechaninès energijos sudaro potencinè energija, pagal ją gali būti nustatoma kinetiné galia, t. y. $P_{k}=f\left(P_{p}\right)$. Tuo tikslu būtina plačiau ištirti $\dot{F r}$ koeficientą. Neries atveju tèkmès skerspjūvių vidutinę kinetinę galią galima ivertinti ryšiu $P_{k}=0,013 P_{p}$.

Praplètus šio universalaus kinetiškumo parametro $\dot{F r}$ tyrimą ir norint įsitikinti jo efektyvumu, buvo sudarytas grafikas, vaizduojantis ryši tarp tèkmès greičio $v$ bei jo nulemto slègio aukščio $h$ ir tèkmès skerspjūvio vidutinio gylio $D_{\text {vid }}$, stebèto prie įvairių $(0,4-0,6 \mathrm{~m} / \mathrm{s})$ srovés greičių (3 pav.).

Ties nagrinètais tèkmès greičiais pateiktas $\dot{F r}$ skaičius, kaip $h_{s}$ ir $h$ santykis (7). Iš grafiko matyti, kad padidejus $v$ nuo 0,4 iki $0,6 \mathrm{~m} / \mathrm{s}$, t. y. 1,5 karto, $h_{s}$ išauga 2,2 karto, o $\dot{F r}-1,6$ karto, kadangi šiuo atveju tèkmès gylis taip pat padidejja, tiesa, mažiau (1,4 karto). Kaip matyti, $\dot{F r}$ sparčiau auga didejjant tèkmès greičiui nei tèkmès gyliui. Gautas tiesinis priklausomumas leidžia spręsti apie $\dot{F r}$ žinant galimus srovés greičius upejje (3 pav.). Pavyzdžiui,

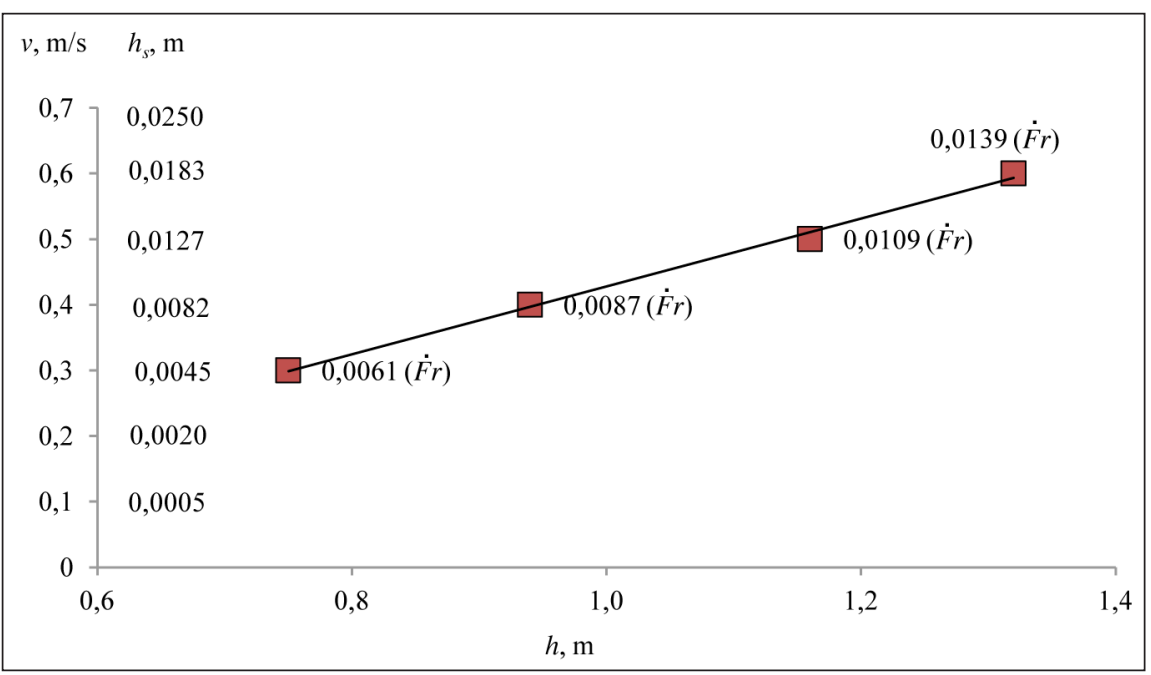

3 pav. Neries kinetiškumas $\dot{F r}$ atsižvelgiant į tèkmės greitį $v(\mathrm{~m} / \mathrm{s})$ ir slègio aukštį $h(\mathrm{~m})$ 
Neryje tèkmès greičiams padidejjus 3 kartus $(0,3-$ $0,9 \mathrm{~m} / \mathrm{s}$ diapazone), $\dot{F r}$ padides nuo 0,0061 iki 0,0213 , t. y. 3,5 karto.

\section{HIDROENERGIJOS GALIA NERIES TÉKMĖS RUOŽUOSE}

Nagrinèjant upès skerspjūvių vandens energiją pastebèta, kad ruožo vidutinis ilgis $5,45 \mathrm{~km}$, jo vidutinis kritimo aukštis $\Delta h=2,05 \mathrm{~m}$. Apskaičiuotos 43 ruožų, esančių tarp nagrinètų 44 pjūvių, vidutinè lyginamoji (kilometrinè) kinetinè ir potencinè galia bei jų Frudo skaičius. Ruožų kritimo aukščiai nustatyti pagal žemèlapiuose pateiktus vandens lygio absoliučius aukščius.

Visos upès $(234,5 \mathrm{~km})$ kilometrinių ruožų galių vidutinès reikšmès yra: $P_{k}=2,04, P_{p}=273,3$ ir $P_{m}=275,4 \mathrm{~kW} / \mathrm{km}$. Pagal šias reikšmes galima spręsti apie atskirų ruožų energetinę vertę, pirmiausia kinetinès energijos požiūriu. Toks vertinimas atliktas Neries upeje pagal Frudo skaičių: $\dot{F r}=P_{k}: P_{p}=0,0075$. Tad Neries lyginamoji kinetinè energijos galia siekia vos $0,75 \%$ potencinès lyginamosios galios. Pagal ši santykị upèje galima nustatyti atkarpas, kur kinetinès energijos potencialas pakankamai didelis nepatvankinèms turbinoms iqrengti. 4 pav. pateikti lyginamosios kinetinès galios ir Frudo skaičiaus grafikai.

Mažesnès už vidurkị kinetinès galios vienam upès kilometrui $\left(P_{k} / \mathrm{km}\right)$ reikšmès yra upès aukštupyje iki Vokès žiočių, o žemupyje nustatyti keli bendro $22 \mathrm{~km}$ ilgio ruožai, kurių kinetinè galia didesnè nei $4 \mathrm{~kW} / \mathrm{km}$, iš jų išsiskiria du $5,2 \mathrm{~km}$ bendro ilgio ruožai su 6,2 ir $6,5 \mathrm{~kW} / \mathrm{km}$

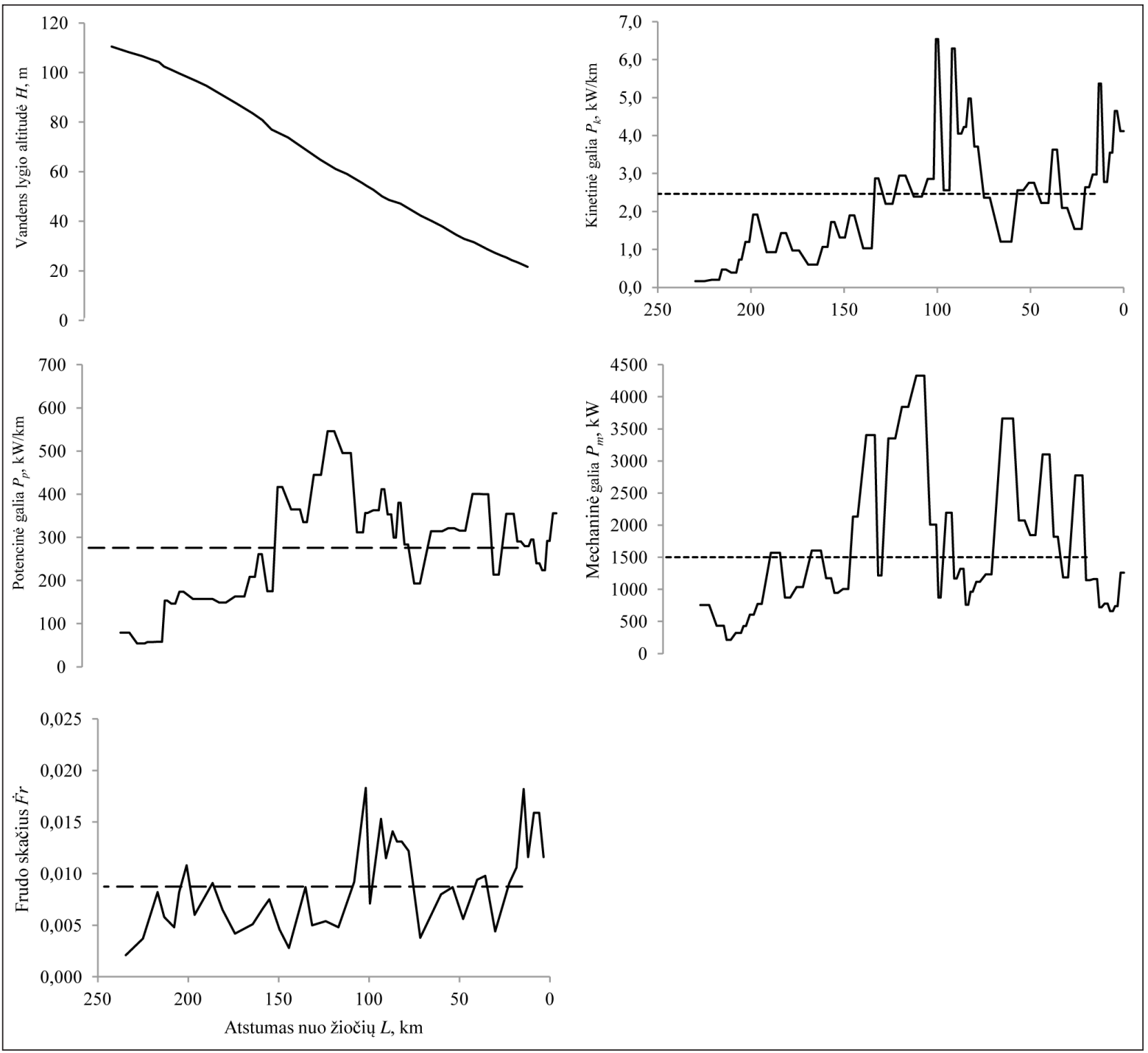

4 pav. Neries tėkmės ruožų vandens lygio altitudè, galios bei Frudo skaičius (punktyrais atidètos vidutinès reikšmės) 
kilometrine kinetine galia. Jų $\dot{F r}$ atitinkamai lygūs 0,0153 ir 0,0189 , t. y. juose kinetiné energijos galia siekia 15,3 ir $18,3 \%$ potencinés energijos galios. Tai aukščiausios kinetinès energijos galių reikšmès visoje tirtoje upeje.

Atliktas tyrimas rodo, kad sausmečiu, kuris tęsiasi apie pusę metų, bet kokio dydžio upèse, kurių srovès greitis nuo 0,3 iki $0,6 \mathrm{~m} / \mathrm{s}$, didelio kinetinès energijos efekto tikètis neverta. Tačiau moksliniu ir praktiniu požiūriais šios krypties tyrimus būtina tęsti dèl atsinaujinančių išteklių technologijų plètojimo ir ekologinių sumetimų. Ypač reikètų atkreipti dèmesi i šalies upių srovès greičių ir gylių režimą, jų susidarymo aplinkybes.

\section{IŠVADOS}

1. Straipsnyje panaudota topografiniuose žemèlapiuose skelbiama hidrometriné informacija sudaro galimybę ìvertinti upès hidroenergijos išteklius. Duomenys atspindi vidutinio vandeningumo metu gegužès-rugpjūčio mèn. vidutines hidromorfologinių parametrų reikšmes.

2. Nustatyta, kad Lietuvos teritorijoje Neries nuolydis yra $37,6 \mathrm{~cm} / \mathrm{km}$, gylis $0,9-3,0 \mathrm{~m}$, vandens sroves greitis $0,3-0,7 \mathrm{~m} / \mathrm{s}$ ir vagos plotis nuo 60 iki $200 \mathrm{~m}$.

3. Neries bendroji hidromechaninè (teorinè) lyginamoji (kilometrinè) energija yra 275,4 kW/ $\mathrm{km}$, ją sudaro $273,3 \mathrm{~kW} / \mathrm{km}$ potencinès ir 2,0 kW/ km kinetinès energijos.

4. Nustatytas upès skerspjūvių Frudo skaičius $\dot{F r}$ svyruoja nuo 0,0034 iki 0,0229 (vidutine reikšmé 0,0127), ruožų $\dot{F r}=0,021-0,0183$ (vidutinè reikšmé 0,00875 ), o visos upés $\dot{F r}=0,0075$.

5. Frudo skaičius rodo, kad Neries kinetinè energija vidutiniškai sudaro $0,732 \%$ potencinès arba $0,726 \%$ visos hidromechaninès energijos.

6. Upejje nustatyti ruožai arba skerspjūviai, kur kinetinès ir potencinès energijų santykis siekia $1,8-2,3 \%$.

7. Upès nuosèkio laikotarpio kinetinès energijos panaudojimas be hidrotechninių priemonių dar nèra perspektyvus, tačiau išsamiau ištirti šalies upių gylius ir pločius bei srovès greičius mokslui ir praktikai - būtina.

8. Nustatyta, kad tèkmès kinetiškumas $(\dot{F r})$ sparčiau auga didejjant tẻkmès greičiui nei tèk- mès gyliui: padidèjus $v$ nuo 0,3 iki $0,9 \mathrm{~m} / \mathrm{s}, \dot{F r}$ padidètų 3,5 karto $(0,0061-0,213)$.

Gauta 20150915

Priimta 20151215

\section{Literatūra}

1. Lietuvos Respublikos Vyriausybès $2004 \mathrm{~m}$. rugsejo 8 d. nutarimas Nr. 114 „Dèl ekologiniu ir kultūriniu požiūriu vertingų upių ar jų ruožų sąrašo patvirtinimo“. Valstybès žinios. 2004. Nr. 137-4995.

2. Jablonskis J., Jurgelènaitè A., Tomkevičienè A. Lithuanian hydropower and environment protection. Environmental Engineering: 7th International Conference, Vilnius Gediminas Technical University, May 22-23, 2008, Vilnius. Vol. 557-562.

3. Lietuvos energetika 11. Kaunas: LEI, 2012. 17 p.

4. Punys P., Ruplys B. Šalies hidroenergetika - blèstančios perspektyvos. Energijos erdve. 2011. Nr. 3(10). P. 4-11.

5. Punys P., Vaišvila A. Nepatvankinès hidroelektrinès. Žemetvarka ir hidrotechnika. 2012. Nr. 4. P. 48-57.

6. Punys P., Martinaitis E., Vaičienè G., Vaišvila A. Neries upès tèkmès hidrokinetinès galios charakteristikų vertinimas vienmačiu modeliu HECRAS 4.1. Vandens ūkio inžinerija. 2013. Nr. 42(62). P. 61-71.

7. Jakimavičius D., Gailiušis B., Šarauskienė D., Jurgelènaitė A., Meilutytė-Lukauskienė D. Assessment of the river in hydrokinetic resources in Lithuania. Baltica. 2014. Vol. 27(2). P. 141150 .

8. Punys P., Adomaitytė J., Kvarciejus A., Žilinskas S. Hydraulic-geometric characteristics of the River Nemunas for the assessment of hydrokinetic resources. Agricultural Engineering. Research paper. 2013. Vol. 45(3). P. 38-50.

9. HEC-RAS River Analysis System. Hydraulic Reference Manual. USACE HEC. Davis, California. Version 4.1. 2010.

10. Assessment of Canada's Hydrokinetic Power Potential. Phaee 1Report. Methodology and Data Review. NRC-CHC. Prepared for: Natural Resources Canada. CanmetENERGY, 2010. 72 p. 
11. Assessment and Mapping of the Riverline in Hydrokinetic Energy Resource in the Continental United States. EPRI, Polo Alto, USA, 2012. 80 p.

12. Resursy poverkhnostnykh vod SSSR. T. 4. Vyp. 3. Opisanie rek, ozer i vodokhranilishch. Vilnius, 1973. $624 \mathrm{~s}$.

13. Gailiušis B., Jablonskis J., Kovalenkovienè M. Lietuvos upés. Hidrografija ir nuotèkis. Kaunas, 2001. $792 \mathrm{p}$.

14. Jablonskis J., Lasinskas M. Lietuvos TSR upiu kadastras. III d. Debitai, nuolydžiai, galingumai. Vilnius, 1962. 640 p.

\section{Jonas Jablonskis, Diana Meilutytè-Lukauskienė}

\section{HYDRO ENERGY OF NERIS RIVER}

\section{Santrauka}

The article presents river flow (by the Neris River) as a mechanical source of hydroelectricity, which consists of potential and kinetic hydropower. Quantity and re- lation between potential and kinetic energy are very essential in order to assimilate local renewable energy resources. The database consists of topographic maps (1:25000) with hydrographics characteristics, which reflect the river drought period. The data series of river stream velocity, river width, river depth, river cross-section area, and slope were made, as well as analysis of these data by the river flow was performed. For the evaluation of the flow of the cross-section of the Neris River, the Froude number $(\dot{F r})$ was defined as a relation between kinetic and potential power, which were separately calculated from kinetic and potential energy. The results indicate that kinetic power is $(0.34-2.3) \%$ of potential power when flow velocity is $v=(0.5-0.6) \mathrm{m} / \mathrm{s}$ during the river drought period. Therefore, it was determined that a more detail investigation of river flow velocity (acceleration), depth, and hydroenergy resources is needed.

Key words: river, kinetic energy power, cross-section area, slope, water velocity, pitch, the Froude number 